\title{
A MAGYAR TUDOMÁNYOS AKADÉMIA ÉS A HATÁRON TÚLI MAGYAR TUDOMÁNYOSSÁG KAPCSOLATA
}

Dr. Morvai Tünde

\begin{abstract}
ABSZTRAKT
Tanulmányomban a Magyar Tudományos Akadémia és a határon túli magyar tudományosság kapcsolatának jelenlegi helyzetét mutatom be. A rendszerváltást követő első évtizedben az Akadémia megteremtette a pénzügyi és személyi alapjait annak, hogy az ezredfordulóra építkezni tudjon a határon túli magyar tudós közösség. Első körben a külső köztestületben, majd ezt követően már saját regionális szervezeteik megalakításával, továbbfejlesztésével, saját irányvonalak kijelölésével vették kezükbe az irányítást. Miközben a Domus Ösztöndíjprogram továbbra is stabil kutatási lehetőséget biztosít a kutatóknak, a Magyar Tudományosság Külföldön Elnöki Bizottság immár a Kárpát-medencén kívül élő magyar tudós közösségeket is összefogja.
\end{abstract}

A Magyar Tudományos Akadémiáról (MTA) szóló 1994. évi XL. törvény módosításáról szóló 2009. évi XX. törvény értelmében az Akadémia közfeladata: „kapcsolatot tart a külföldön élő magyar nyelvű és tárgyú tudományos kutatások múvelőivel, támogatja a határon túli magyar tudományosságot." ${ }^{11}$ Kettős feladatkörét a Magyar Tudományosság Külföldön Elnöki Bizottság (MTK EB) az MTA Titkársága operatív végrehajtásáért felelős szervezeti egysége, a Határon Túli Magyarok Titkársága (HTMT) közremúködésével látja el.

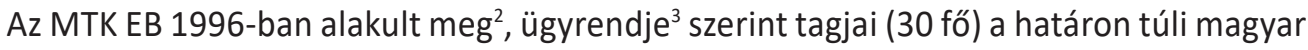
tudományos élet kiemelt kutatói, valamint a határon túli magyar tudományos szervezetek képviselői. Magyarországi tagjai a külföldi magyar tudományosság iránt elkötelezett kutatók, elsősorban az MTA korábbi kutatóintézeteiben foglalkoztatott munkatársak. Az MTK EB elnökét és tagjait - a HTMT vezetője kivételével - az Akadémia elnöke kéri fel hároméves időszakra, amely időszak megegyezik az Akadémia elnökének mandátumával. ${ }^{4}$

\footnotetext{
${ }^{1}$ A Magyar Tudományos Akadémiáról szóló 1994. évi XL. törvény, a Magyar Tudományos Akadémia Alapszabálya és Ügyrendje egységes szerkezetben. Forrás: https://mta.hu/data/dokumentumok/hatteranyagok/akademiai szabalyozasok/ALAPSZABALY EGYSEGES 20150331 januar1.pdf [2020. június 20.]

${ }^{2}$ Az MTK EB megalakulásának huszadik évfordulója alkalmából megjelent A nemzet mint tudományos közösség. Húszéves a Magyar Tudományos Akadémia Magyar Tudományosság Külföldön Elnöki Bizottság (1996-2016) címú nyomtatott és elektronikus kiadvány, amely történeti áttekintést nyújt a rendszerváltástól 2016-ig az Akadémia és a határon túli magyar tudományosság kapcsolatának alakulásáról. FEDINEC Csilla (szerk.): A nemzet mint tudományos közösség. Húszéves a Magyar Tudományos Akadémia Magyar Tudományosság Külföldön Elnöki Bizottság (1996-2016). Budapest, MTA MTK EB, 2016.

${ }^{3}$ A Magyar Tudományos Akadémia Magyar Tudományosság Külföldön Elnöki Bizottság ügyrendje. Igazgatási Ügyirat.

${ }^{4}$ Az MTK EB jelenlegi tagjainak névsora megtalálható az MTA honlapján: https://mta.hu/magyar-tudomanyossag-kulfoldon/magyar-tudomanyossag-kulfoldon-elnoki-bizottsag-105534
} 
Az MTK EB 2017-ig a Magyarországgal szomszédos országok magyar tudományos szervezeteink képviselőit tudhatta tagjai között, 2017-ben azonban csatlakoztak a nyugati diaszpóra szervezeteinek vezetői is, a Bizottság ezzel a világ magyarságának tudós reprezentánsait tömöríti. A nyugati tudományos szervezetek ezt megelőzően különféle szervezeti formákban múködtek (Nyugati Magyar Tudományos Tanács, Magyar Tudományosság és Kárpát-medencén Kívüli Albizottság) és kötődtek az Akadémiához, míg végül az MTK EB biztosította számukra az MTA-val való intézményes kapcsolattartás lehetőségét.

\section{TÁMOGATÁSI RENDSZER}

Az Akadémia a határon túli magyar kutatók és tudományos mühelyek támogatását a Domus Ösztöndíjprogram múködtetésével biztosítja. Az 1997-ben indult program kezdetben a határon túli magyar kutatók Magyarországon történő kutatásait támogatta ösztöndíjjal, illetve szállással. A program 2001-ben bővült, abban az évben már szülőföldi kutatómunka végzésére is lehetett pályázni. Ezt követően megjelent az igény a csoportos kutatások iránt, így 2003-tól a határon túli kutatók régión belül, és a régiók egymással kooperálva is működtethetnek sikeres pályázat esetén kutatócsoportot. Az egyéni kutatási támogatások köre 2018-ban újabb kategóriával egészült ki, miután megjelent a határon túli kutatók nemzetközi részvételi támogatását előirányzó pályázat, amelynek keretében határon túli PhD-hallgatók, illetve az MTA külső köztestületi tagjai vehetnek részt. A pályázat a kutatók nemzetközi beágyazottságát kívánja szolgálni, ahogy az idén elindított nemzetközi publikációs pályázat is a rangos nemzetközi folyóiratok közlési díjának átvállalásával. A Domus Ösztöndíjprogram 2012 óta elektronikus úton pályázható, a jelentkezési adatok alapján megállapítható, hogy a pályázók túlnyomó többsége (80\%) társadalomtudós és bölcsész.

Meg kell említeni, hogy az Akadémiának vannak olyan programjai, amelyek nem kizárólagosan határon túli kutatóknak szólnak, azonban ők is részt vehetnek ezekben. Kiemelném az MTA Bolyai János Kutatási Ösztöndíjat, amelyre elindításától, 1997-től a határon túli kutatók is pályázhatnak. A Bolyai-díjas határon túli kutatók számára az Akadémia magyarországi tartózkodási idejük alatt szálláshelyet biztosít az Domus 'Collegium Hungaricum'-ban.

Az MTA kiemelt célcsoportja a határon túli magyar tudományos szervezetek. Számukra 2005-ben nyílt meg a lehetőség, hogy működési költségeik fedezésére, illetve rendezvényeikre és könyvkiadásaikra pályázatot nyújtsanak be. A határon túli magyar tudományos szervezeteket az MTK EB tartja nyilván, a Bizottság dönt arról, mely szervezetek folyamodhatnak múködési pályázatért, és melyek csak rendezvény- és konferenciatámogatásért. ${ }^{5}$

\footnotetext{
${ }^{5}$ Az MTK EB által nyilvántartott határon túli magyar tudományos szervezetek listája: https://mta.hu/magyar-tudomanyossag-kulfoldon/ karpat-medencei-magyar-tudomanyos-muhelyek-105581
} 
A Nemzetközi Főosztály - az egykori akadémiai kutatóintézetek és kutatócsoportok mellett - a legjelentősebb határon túli magyar tudományos szervezeteknek is lehetőséget biztosít nemzetközi konferenciaszervezési pályázatban való részvételre, hogy támogassa nemzetközi tudományos kapcsolataik előmozdítását, ápolását.

A Domus 'Collegium Hungaricum'-ot (DCH) 1999-ben bocsátotta az akkori oktatási minisztérium a Domus Ösztöndíjprogramjának szolgálatába abból a célból, hogy az ösztöndíjprogramban résztvevő, Budapesten tudományos tevékenységet folytató határon túli magyar kutatóknak térítésmentes szállást tudjon biztosítani. Az épületet a kormány 2011-ben 15 évre az Akadémia tulajdonába utalta. A DCH azon túl, hogy térítésmentesen tudja elszállásolni az ösztöndíjasokat, kedvezményes áron bocsátja rendelkezésre szobáit a határon túli magyar köztestületi tagoknak és külső tagoknak. A külső tagok számára évi 14 napon térítésmentesen biztosít szállást. A DCH azonban nem csupán szálláshely, rendelkezik konferenciateremmel és könyvtárszobával. A konferenciateremben lehetőség van az ösztöndíjasoknak saját kutatási eredményeik bemutatására, de más határon túli kutatók számára is nyitott rendezvények tartására. A könyvtár gyűjteményének különlegessége, hogy megtalálhatóak benne az ösztöndíjasok eddig megjelent munkái, illetve a legfontosabb kisebbségtudományi szakirodalom.

\section{KAPCSOLATTARTÁS}

Az MTA hazai köztestületéről az 1994. évi akadémiai törvény rendelkezett, a határon túli magyar kutatók 2000 óta jelentkezhetnek az Akadémia külső köztestületébe. Az Akadémia Alapszabálya (23. §. (1)) szerint: „A köztestület külső tagjává az az életvitelszerűen külföldön élő, tudományos tevékenységet külföldön folytató kutató válhat, aki hazájában, illetve Magyarországon elismert tudományos fokozattal rendelkezik, tudományát alkotó módon múveli, magát magyarnak vallja, és kapcsolatot tart a magyar tudományos élettel". ${ }^{6}$ Az Alapszabályban lefektetett feltételeknek megfelelő határon túli kutatók külső köztestületi jelentkezésüket az Akadémiai Adattáron keresztül kitöltött és aláírt belépési nyilatkozattal, valamint tudományos fokozatuk igazolásával tudják kezdeményezni. Jelentkezésük elfogadásáról az MTK EB dönt. Kedvező döntést követően elnöki aláírással hitelesített oklevéllel értesíti a kutatót a külső köztestületbe történő befogadásáról.

A külső köztestületi tagsággal a HTMT közvetlenül tud kapcsolatot tartani. A tagokat folyamatosan értesíti a pályázati lehetőségekről, rendszeresen, havonta elektronikusan küldi a külföldi magyar tudományosságról szóló MTK EB hírlevelet. A külső köztestületi tagság lehetőség az MTA-val való folyamatos kapcsolattartásra, az Akadémia pályázatainál pedig feltétel a tagság: csak azok nyújthatnak be pályázatot, akik tagjai a köztestületnek.

${ }^{6}$ A Magyar Tudományos Akadémiáról szóló 1994. évi XL. törvény (MTAtv.), a Magyar Tudományos Akadémia Alapszabálya és Ügyrendje egységes szerkezetben. Forrás: https://mta.hu/data/dokumentumok/hatteranyagok/akademiai szabalyozasok/ALAPSZABALY EGYSEGES 20150331 januar1.pdf [2020. június 20.] 
A tudományos osztályok akadémiai törvényből fakadó feladata, hogy „,kapcsolatot tart a határon túli magyar tudományosság képviselőivel, a köztestület külső tagjaival."7

Jelenleg a külső köztestület 1816 tagból áll: a legtöbb külső köztestületi tag Románia területéről származik (905 fő), ahol a legjelentősebb magyar közösség él. Ezt követően azonban már nem a határon túli magyar közösségek számarányának megfelelő a külső köztestületi tagok aránya (230 fő Szerbia, 211 fő Szlovákia, 169 fő Ukrajna, 103 fő az Amerikai Egyesült Államok területéről).

A külső tagok és külső köztesületi tagok között tudományterületi besorolás szerint jelentős eltérés mutatkozik (ld. 1. ábra). A külső köztestületi tagok közel fele (47,13\%) tartozik a humán- és bölcsészettudományi osztályokba, ez az arány a külső tagoknál 19,58 \%. A külső tagság szinte azonos arányban - 40-40\% - oszlik meg a természettudományi (matematikai, műszaki, földtudományi), illetve az élettudományi (agrár, orvosi, kémiai, biológiai) tudományterülethez tartozó osztályokban.

1. ábra. A külső tagok és külső köztestületi tagok megoszlása tudományos osztályonként (\%)

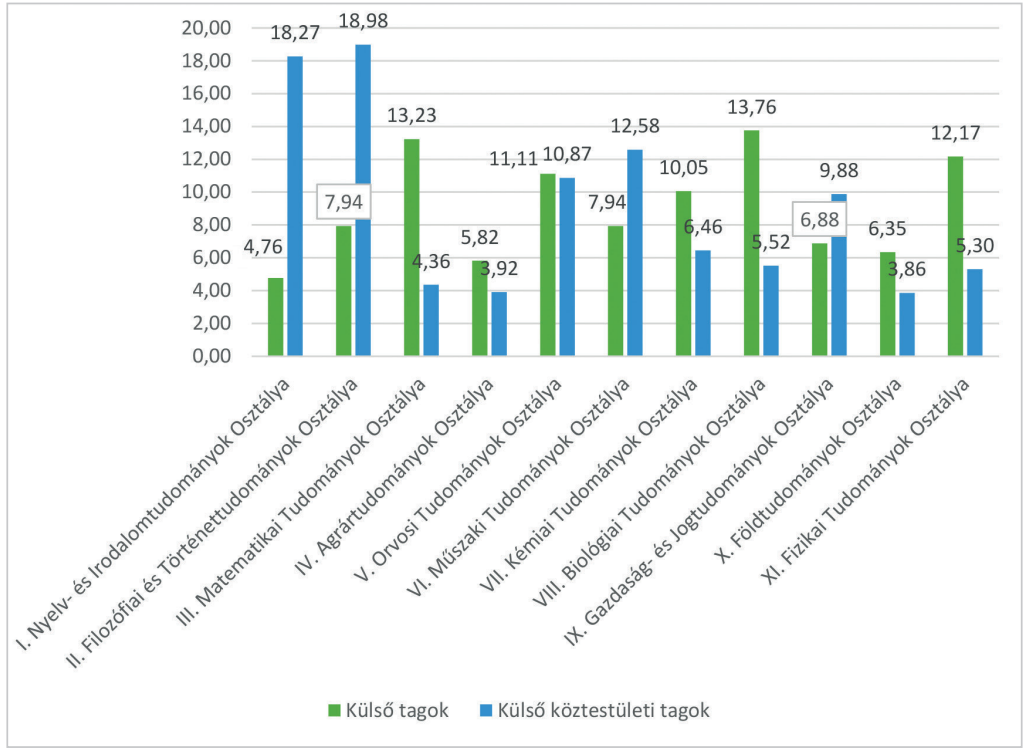

Az Akadémia külső tagságának intézménye ${ }^{8}$ korábban is ismert volt, azonban 1990-ben új tartalommal jelent meg: az MTA Alapszabályai és Testületi Ügyrendje (16. §) ${ }^{9}$ szerint

\footnotetext{
7 MTAtv. 10. § (4), Uo.

${ }^{8}$ Az 1869-es MTA Alapszabályai 17 .§. szerint: „A külső tagok azon nem magyarul iró tudósok sorából választandók, kik vagy a tudományosság körül érdemeik által hírt szereztek, vagy Magyarországot, vagy az Akadémiát közelebbről érdeklő munkával az Akadémia különös kitüntetésére méltókká lettek. Az Akadémia mindennemű ülésében székök van.” Ld. KÓNYA Sándor: „...a Magyar Akadémia állíttassék fel...” Akadémiai törvények, alapszabályok, ügyrendek 1827-1990. Budapest, MTA Könyvtára, 1994. 135. p.

${ }^{9}$ MTA Alapszabályai és Testületi Ügyrendje 1990. In: Uo.
} 
a külföldi, magát magyarnak valló kutatót lehet külső taggá választani. A cél a külföldön élő magyar tudósok hazai akadémiai életbe való integrálása volt. Az Akadémia a rendes és levelező tagválasztáshoz hasonlóan háromévente választ külső tagokat, a külső tagok azonban az Akadémia közgyúlésén nem rendelkeznek szavazati joggal, kizárólag tanácskozási joggal vehetnek azon részt. Jelentős különbség, hogy tiszteletdíjban csak a Kárpát-medencében élő külső tagok részesülnek. A külső tagok (189 fő) földrajzi eloszlása jelentősen különbözik a külső köztestületi tagokétól, a legtöbb külső tag az Amerikai Egyesült Állomokban él (81 fő), a Kárpát-medence országaiban pedig további 31 fő. ${ }^{10}$

Az MTA külső tagjait a HTMT szintén folyamatosan tájékoztatja az aktuális pályázati lehetőségekről, és havonta kapják az MTK EB hírlevelét. Emellett a külső tagok bekapcsolódhatnak a tudományos osztályok munkájába.

Az MTA éves rendes közgyúlése keretében minden évben megrendezi a Külső Tagok Fórumát, ahol többek között átadják a határon túli kutatók számára az Arany János-díjakat és -érmet, valamint tudományos előadásokat tartanak a külső tagok, illetve a külső köztestületi tagok. Az évenként megrendezett Külső Tagok Fóruma lehetőséget biztosít a tagoknak a rendszeres személyes kapcsolattartásra. A Fórumon a díjakat az Akadémia mindenkori elnöke adja át.

Az MTA az Arany János-díjat (2004 óta) és -érmet (2002 óta) a határon túli magyar tudósok munkájának elismerésére alapította. Az MTK EB három kategóriában ítél oda Arany János-díjat: Életműdíj, Kiemelkedő Tudományos Teljesítmény Díj, Fiatal Kutatói Díj. Az érem nem, a díj viszont pénzjutalommal is jár, ötszázezer, háromszázezer és kétszázezer forint értékben. Az Arany János-díj elsősorban a határon túli magyar kutatók tudományos teljesítményének díjazására szolgál; az Arany János-érem viszont a külhoni magyar tudományos közélet szervezésében, irányításában, az egyetemi oktatásban, tudományos könyvkiadásban, muzeológiai, levéltári, könyvtári munkában, tudományos ismeretterjesztésben, azaz általában a külhoni magyar tudományosság és közösség ügyének előmozdításában szerzett kiemelkedő érdemekért ítélhető oda. ${ }^{11}$

Magyarország területén már évtizedek óta működnek az MTA területi bizottságai mint az adott régió tudományos életének szervezői. Ennek mintájára jöttek létre a Magyarország határain túli akadémiai területi szervezetek. Elsőként, 2007-ben a Kolozsvári Akadémiai Bizottságot (KAB) hozta létre a romániai magyar tudós közösség, amely szervezet a magyarországi területi bizottságok sorába tartozik. A három kisebb magyar közösség akadémiai tanácsot hozott létre: időrendben elsőként a Vajdasági Magyar Akadémiai Tanács (2008), a Szlovákiai Magyar Akadémiai Tanács (2014) majd a Kárpátaljai Magyar

${ }^{10}$ A 31 fóből 22 romániai, 5 szlovákiai, 2-2 ukrajnai és szerbiai.

11 TARNÓCZY Mariann - KÖVÉR Alexandra (szerk.): Tudomány és Magyarság. Arany János-díj és -érem 2002-2010. MTK EB, Budapest, 2010. 
Akadémiai Tanács (2015) alakult meg. A négy Kárpát-medencei akadémiai szervezet múködését az MTA finanszírozza éves múködési költség biztosításával.

A KAB mint a legnagyobb köztestületi tagsággal rendelkező szervezet, a különböző tudományterületeket lefedve rendelkezik szakbizottságokkal, illetve a köztestület földrajzi elhelyezkedéséhez igazodva regionális munkabizottságokat is működtet Bánsági és Bukaresti Regionális Munkabizottság néven.

A három akadémiai tanács minden évben szervez tagsága számára legalább egy nagyobb volumenű konferenciát, ahol immár hagyománnyá vált, hogy kiemelkedő kutatóiknak díjakat adnak át. A szervezetek a tudományos utánpótlás felkarolására különös figyelmet fordítanak.

Az Amerikai Egyesült Államokban is megfogalmazódott az igény területi bizottság alakítására. Fontos előzménye volt, hogy 2016-ban megalakult az Amerikai Magyar Akadémikusok Társasága (AMAT). A szervezet ezt követően évente szervez az Amerikai Egyesült Államok különböző városaiban konferenciát, ahol az ott élő magyar tudósok ismertetik legújabb kutatási eredményeiket, emellett a konferencia éves kapcsolattartási pont is a magyar kutatók számára. 2018-ban az AMAT mellett még három tudományos szervezet (Bostoni Tudósklub, New York-i Magyar Tudományos Társaság, Nyugati Parti Magyar Tudósklub) összefogásával létrejött az MTA Amerikai Magyar Bizottsága.

A magyarországi területi bizottságok és a határon túli $K A B$, illetve a három Kárpát-medencei akadémiai tanács évi két alkalommal találkozik: egyrészt minden év elején, ahol egyeztetik éves programjaikat, másrészt tavasszal a területi bizottságok találkozóján, amelyet minden évben más helyszínen szerveznek meg, így határon túli helyszínen is sor került már erre a találkozóra.

Az MTA november havi Magyar Tudomány Ünnepe rendezvénysorozata kiterjed a határon túli magyar területekre is, a KAB és a többi akadémiai tanács, valamint több határon túli magyar tudományos szervezet is szervez ez alkalomból konferenciákat, különféle tudományos programokat. A több mint 160 éves múlttal rendelkező Erdélyi MúzeumEgyesület, 2002 óta a szervezet megalakulásának évfordulójának napján (november 23-án) tartja a Magyar Tudomány Napja Erdélyben eseményt, csatlakozva az MTA rendezvénysorozatához.

\section{ÖSSZEFOGLALÓ}

A MTA és a határon túli magyar tudományosság kapcsolatának rövid bemutatása a jelen helyzet vázolására koncentrált, nem kívánta kronologikusan elemezni ennek a kapcsolatnak a fejlődéstörténetét. Ennek ellenére jól látható a fejlődési ív. A kilencvenes évek végén az 
MTA lerakta a határon túli magyar tudományosság támogatási rendszerének alapköveit a finanszírozás és a kapcsolatok kiépítése terén. Ma már a határon túli magyar köztestület önálló akadémiai szervezetekkel rendelkezik, szervezi saját tagsága tudományos életét, erős magyarországi és más régiók szakmai kapcsolatainak birtokában. Teszik mindezt úgy, hogy az MTA a több mint húsz éve elindított programjait igyekszik külső köztestülete igényeinek megfelelően formálni, amelynek jelenlegi fő iránya a határon túli magyar tudományosság nemzetközi tudományos életbe való beágyazottságának erősítése.

\section{IRODALOMJEGYZÉK}

FEDINEC Csilla (szerk.): A nemzet mint tudományos közösség. Húszéves a Magyar Tudományos Akadémia Magyar Tudományosság Külföldön Elnöki Bizottság (1996-2016). Budapest, MTA MTK EB, 2016.

KÓNYA Sándor: „....a Magyar Akadémia állíttassék fel...” Akadémiai törvények, alapszabályok, ügyrendek 1827-1990. Budapest, MTA Könyvtára, 1994.

A Magyar Tudományos Akadémia Magyar Tudományosság Külföldön Elnöki Bizottság ügyrendje. Igazgatási Ügyirat.

A Magyar Tudományos Akadémiáról szóló 1994. évi XL. törvény (MTAtv.), a Magyar Tudományos Akadémia Alapszabálya és Ügyrendje egységes szerkezetben. Forrás: https://mta.hu/data/dokumentumok/hatteranyagok/akademiai szabalyozasok/ALAPSZABALY EGYSEGES $201503 \quad 31$ januar1.pdf [2020. június 20.]

TARNÓCZY Mariann - KÖVÉR Alexandra (szerk.): Tudomány és Magyarság. Arany János-díj és -érem 2002-2010. MTK EB, Budapest, 2010.

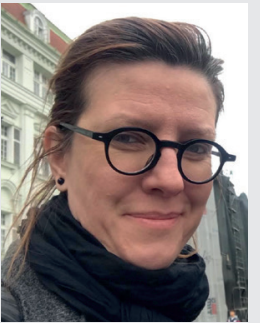

Dr. Morvai Tünde (ORCID: 0000-0003-0898-8351)

Párkányban született, az Eötvös Loránd Tudományegyetem Állam- és Jogtudományi Karon szerzett politológus diplomát, majd az Eötvös Loránd Tudományegyetem Pedagógiai és Pszichológiai Kar Neveléstudományi Doktori Iskolájában doktorált. A neveléstudományok doktora, az MTA Testületi Titkárság Határon Túli Magyarok Titkárságának osztályvezetője. Kutatási területe: a szlovákiai magyar oktatás, kisebbségi elit, ifjúság. 